\title{
Røys som fenomen. Rydning eller grav?
}

\author{
ASTRID HOELSETH BJØRLO
}

Bjørlo, A. H. 2020. Cairns as phenomena. Clearance- or burial cairns? AmS-Varia 61, 31-41, Stavanger. ISSN 0332-6306, ISBN 978-82-7760-187-8.

\begin{abstract}
Cairns in one form or another are the most common type of prehistoric structure encountered during archaeological surveys in Rogaland County, southwestern Norway. In Norway, the responsibility for pre-development archaeological investigations is divided between county archaeologists and regional museums with the former undertaking site identification surveys and the latter carrying out subsequent excavations. Archaeological surveying is typically non-invasive and distinguishing burial cairns from clearance cairns often proves to be a difficult task. It is frequently argued that separating the two categories based on size and form alone is not sufficient. In this article, it is shown that, in addition to visual analysis, an understanding of the surrounding prehistoric landscape within which the cairn is situated is crucial when interpreting these structures. The interpretive utility of new methodologies such as Lidar and analysis of soil identification maps are also highlighted. Arguments are based primarily on data from localities containing cairns encountered during the E39 Ålgård-Hove project carried out in 2016 by Rogaland County, as well as a site excavated by the Museum of Archaeology, University of Stavanger in 2011.
\end{abstract}

Astrid Hoelseth Bjørlo, Rogaland County, N-4010 STAVANGER, NORWAY. E-mail: astrid.bjorlo@rogfk.no

Keywords: burial cairn, clearance cairn, prehistoric landscape, location, Iron Age.

\section{Innledning}

I forbindelse med visuell overflateregistrering er røyser den fornminnekategorien fylkesarkeologene i Rogaland registrerer hyppigst. Ved registrering i utmark må registranten avgjøre hvorvidt det dreier seg om natur eller kultur, rydning eller grav, kun ut fra røysens ytre trekk. Tidligere ble mindre røyser nærmest automatisk regnet for å være rydningsrøyser hvis de i det hele tatt ble tillagt noen oppmerksomhet. Rydningsrøyser ble lenge ansett som en mindre interessant og utsagnsvak kulturminnekategori (Holm, 1995, s. 15; Haavaldsen, 1999, s. 13). Å skille rydningsrøyser fra gravrøyser ut fra form og størrelse har imidlertid vist seg å være problematisk, da utgravninger har vist at mindre og uanselige røyser har skjult funnrike graver (Børsheim, 1997; Bjørlo, 2012; Fyllingen \& Armstrong, 2012). Samtidig finnes det både små og store funnfattige røyser, eller røyser uten gjenstandsfunn, som ut fra kontekst og jordkjemiske analyser viser seg å være graver (Bortheim \& Dahl, 2014; Rødsdalen \& Bjørdal, 2017). Gravrøyser er med andre ord mangfoldige. Skillet mellom hva som er grav og hva som er rydning er diffust og krevende å avgjøre selv i en utgravningssituasjon. Ved registrering spiller derfor plasseringen i landskapet, samt fravær eller tilstedeværelse av andre kulturminner, en avgjørende rolle i tolkningen. Denne artikkelen er et forsøk på å vise hvordan røysenes ytre trekk, sammen med landskapsanalyse og andre metoder, blir anvendt som tolkningsgrunnlag $\mathrm{i}$ en registreringssituasjon. Artikkelens problemstilling vil bli eksemplifisert ved registreringsprosjekt E39 Ålgård-Hove som ble gjennomført i 2016, i tillegg til en røyslokalitet som ble undersøkt av Arkeologisk museum/UiS i 2011.

\section{Røysenes utvikling i tid og rom}

Å skille rydningsrøyser og gravrøyser kan være problematisk av ulike årsaker. Registranter forholder seg ofte til røyser i utmark, hvor tett vegetasjon, tykk skogbunn eller gjentakende tilføring av gjødsel kan gjøre små og uanselige røyser vanskelige å erkjenne i marken. Røysenes romlige og landskapsmessige kontekst kan være sterkt endret eller fjernet ved at vann er drenert 
bort, myr er pløyd opp eller at eldre ferdselsveier er borte. Eldre veifar kan også være erstattet med nye veier som skaper en annen strukturering av landskapet. Redusert beiting kan ha resultert i mer og tett skog, og gjengroing av kulturlandskapet kompliserer tolkningsgrunnlaget. Røysenes opprinnelige kontekst kan også ha blitt mer diffus ved at annen forhistorisk eller historisk aktivitet har omstrukturert eller endret området. Samtidig kan graver ha blitt anlagt på et rydningsrøysfelt eller omvendt, eller at gravrøyser senere har blitt tildekket av rydningsstein (Børsheim, 1999, s. 350). Røyser med en tapt eller utydelig kontekst kan også i enkelte landskapsformer være utfordrende å skille fra naturlige steinsamlinger.

Et annet moment som kompliserer tolkningen av røyser er at gravrøyser ikke er en statisk kategori. Gravrøyser viser store variasjoner mellom de ulike forhistoriske periodene når det gjelder størrelse, oppbygning og plassering i landskapet. Betydning av gravrøysen for det forhistoriske menneske har også endret seg mye fra eldre bronsealders enkeltliggende og monumentale hauger til eldre jernalders små og uanselige gravfelt. Selve plasseringen av gravrøyser og gravfelt kommuniserer ulike motivasjoner. Faktorer som blant annet ideologi, sosial rang og sosiopolitiske forhold bidrar til at gravrøysen som en håndfast kategori ikke eksisterer. Dette stiller derfor krav til å «lese» og gjenkjenne de forskjellige forhistoriske lagene i landskapet for å kunne sette røysene inn i sin rette kontekst, samt å vite i hvilket landskap de ulike tidsepokene oftest vil være representert.

Rydningsrøysen som fornminnekategori ble tidligere viet liten interesse, og er en kategori det er blitt forsket lite på. De ble ansett som «lav status»-kulturminner, og man var tidligere villig til å frigi rydningsrøyser og rydningsrøysfelt etter begrenset forutgående undersøkelser eller uten noen undersøkelser overhodet (Børsheim, 1999, s. 348). I de senere årene har imidlertid interessen for rydningsrøyser økt, og man har erkjent at rydningsrøyser er fysiske spor etter et forhistorisk jordbruk (Holm, 1995, s. 15). Samtidig ble det klart hvilket kunnskapspotensial denne fornminnetypen hadde, da undersøkelser viste at rydningsrøyser kunne fungere som «sedimentscontainer» og pollenfeller. Informasjon om blant annet klimaforhold, vegetasjonsutvikling, jordbrukskulturer og driftsformer kan ligge lagret og forseglet i rydningsrøysene. Naturvitenskapelige metoder som pollenanalyse og radiologisk datering ble derfor viktige bidrag for å studere det dynamiske aspektet i landskapet, samtidig som det åpnet opp for muligheten til å rekonstruere fortidens vegetasjon og landskap (Pedersen, 1999, s. 46; Prøsch-Danielsen, 1999, s. 357-360; Hjelle, 2005, s. 91-92).

Forskning omkring det forhistoriske jordbruket har også vist at rydningsrøysenes ytre trekk kan bidra med informasjon om hvilken jordbruksform røysene er et resultat av (Myhre \& Øye, 2002). Rydningsrøyser i kombinasjon med godt ryddete åkerflater og markerte åkerterrasser vitner om et intensivt åkerbruk. Et ekstensivt jordbruk etterlater seg mer diffuse spor, og man vil ofte ha røyser i kasteavstand til hverandre. I tillegg vil den fossile åkerjorden være mindre matjordspreget. I noen tilfeller med ekstensiv dyrkning vil røysene få en punktbrink i overkanten av røysene - et resultat av at jorden har hopet seg opp som en miniterrasse mot overkanten av røysen. I områder kun brukt til beite og slått vil man derimot ikke finne spor etter terrasser eller punktbrinker. Der vil jordsmonnet ha karakter av en vanlig brunjordsprofil (Pedersen, 1990, s. 51,1999 , s. 48).

I enkelte landskapsformer kan også steinstørrelsen i rydningsrøysene benyttes som en kilde til informasjon. Ved bruk av de gamle pløyeredskapene var det hodestore steiner som var til hinder på åkeren. Mindre stein vanskeliggjorde ikke pløyingen og de store steinblokkene kunne man styre unna. Gjennom fortsatt åkerbruk ble åkeren bedre og bedre ryddet for stein slik at også mindre stein til slutt ble ryddet bort. Etter hvert som mekaniseringen av jordbruket skjøt fart, ble også de største steinene fjernet, og rydningsrøysene vokste i størrelse. Lave, nedsunkne og overgrodde røyser bestående av hodestore steiner blir derfor antatt å være eldre enn store røyser med bar stein oppi dagen (Holm, 1995, s. 70; Børsheim, 1999, s. 348; Myhre \& Øye, 2002, s. 92). Med de forskjellige evolusjonsstegene innenfor jordbruket in mente kan man derfor i noen tilfeller se en kronologisk variasjon mellom rydningsrøysene.

Både grav- og rydningsrøysenes variasjon i størrelse og romlig plassering viser kompleksiteten i registreringsarbeidet. For å lykkes med tolkningen på et registreringsnivå er det viktig å ha hjelpemidler og vurderingspunkter å støtte seg til.

\section{Definisjoner og tilnærmingsmetoder}

Før en videre gjennomgang av definisjoner omkring rydnings- og gravrøyser kan det være behov for en avklaring av hvordan røysbegrepet blir videre anvendt. Steinlegging og røys blir gjerne skilt fra hverandre ved at røys har en konveks eller hvelvet overflate. Da rydningsrøyser ikke nødvendigvis innfrir dette kravet, vil det heller ikke settes noe skille mellom steinlegginger og gravrøys i den videre diskusjonen. 
Selv om både rydningsrøyser og gravrøyser endrer karakter over tid og i ulike kulturer, kan det likevel skilles ut noen felles trekk for begge kategoriene. I faglitteraturen (Løken, 1974; Myhre, 1985; Bennett, 1987; Pedersen, 1990, 1999; Holm, 1995, 2003; Dommasnes, 1997; Børsheim, 1999; Myhre \& Øye, 2002; Solberg, 2003; Sjölin, 2015) finnes det ulike definisjoner av rydning- og gravrøyser. Hovedtrekk som anvendes for å beskrive de to kategoriene er i hovedsak:

\section{Gravrøys:}

- planmessig utforming

- jevn og intensjonell oppbygning

- tydelig avgrensning

- homogen steinmasse

- ytre formelementer som kantkjede, sentrumsstein og/eller sentral forsenkning/ grop

- kan ha indre konstruksjoner i form av steinsettinger og kammer

- kan inneholde menneskelevninger og/eller gjenstandsfunn

\section{Rydningsrøys:}

- stein i varierende størrelse

- liten grad av intensjonell oppbygning eller indre struktur

- diffus avgrensing

- plassert rundt eller inntil jordfaste steiner

- kan ha punktbrink

- 2-6 m i diameter
Det siste kulepunktet under rydningsrøyser har imidlertid vist seg å være problematisk, da det i forbindelse med utgravinger de siste årene har framkommet flere rike gravfunn i mindre røyser (Børsheim, 1999, s. 350; Bjørlo, 2012, s. 9-11; Fyllingen \& Armstrong, 2012, s. 41). Mindre røyser er med andre ord ikke synonymt med rydningsrøyser. Heller ikke de øvrige kriteriene er uproblematiske, da bildet er mer nyansert enn som så. Definisjonene kan se enkle ut på papiret, men erfaringsmessig har det vist seg å være vanskelig å skille rydningsrøysfelt fra gravfelt. Store rydningsrøysfelt som er blitt anvendt gjennom flere hundre år lar seg vanskelig skille fra gravfelt med små røyser. Det gjelder spesielt gravfelt fra eldre jernalder som kan bestå av små og lave gravrøyser (Hougen, 1924, s. 20-21; Bennett, 1987, s. 57-59; Solberg, 2003, s. 41 og 76; Rødsrud, 2004, s. 278-279). Gravpraksisen med å grav-legge de døde samlet på gravfelt blir mer vanlig i førromersk jernalder. Da enten på små gravplasser eller på gravfelt som etter flere generasjoners, eller kulturers bruk, kan romme flere hundre graver. Noen steder er gravfeltene lagt i nærheten av gravrøyser eller hauger fra eldre bronsealder som ofte ligger på toppen av åser eller større høydedrag. En beliggenhet i nærheten av store hauger fra bronsealderen kan være for å utvise en stedskontinuitet og bruksrettigheter tilknyttet området (Hougen, 1924, s. 21; Lillehammer, 1994, s. 148; Rødsrud, 2004, s. 276; Wangen, 2009, s. 136). Førromersk jernalder blir ofte betegnet som en funnfattig periode, hvor funnfattigheten viser både til få kjente graver, men også til fraværet av oldsaker i

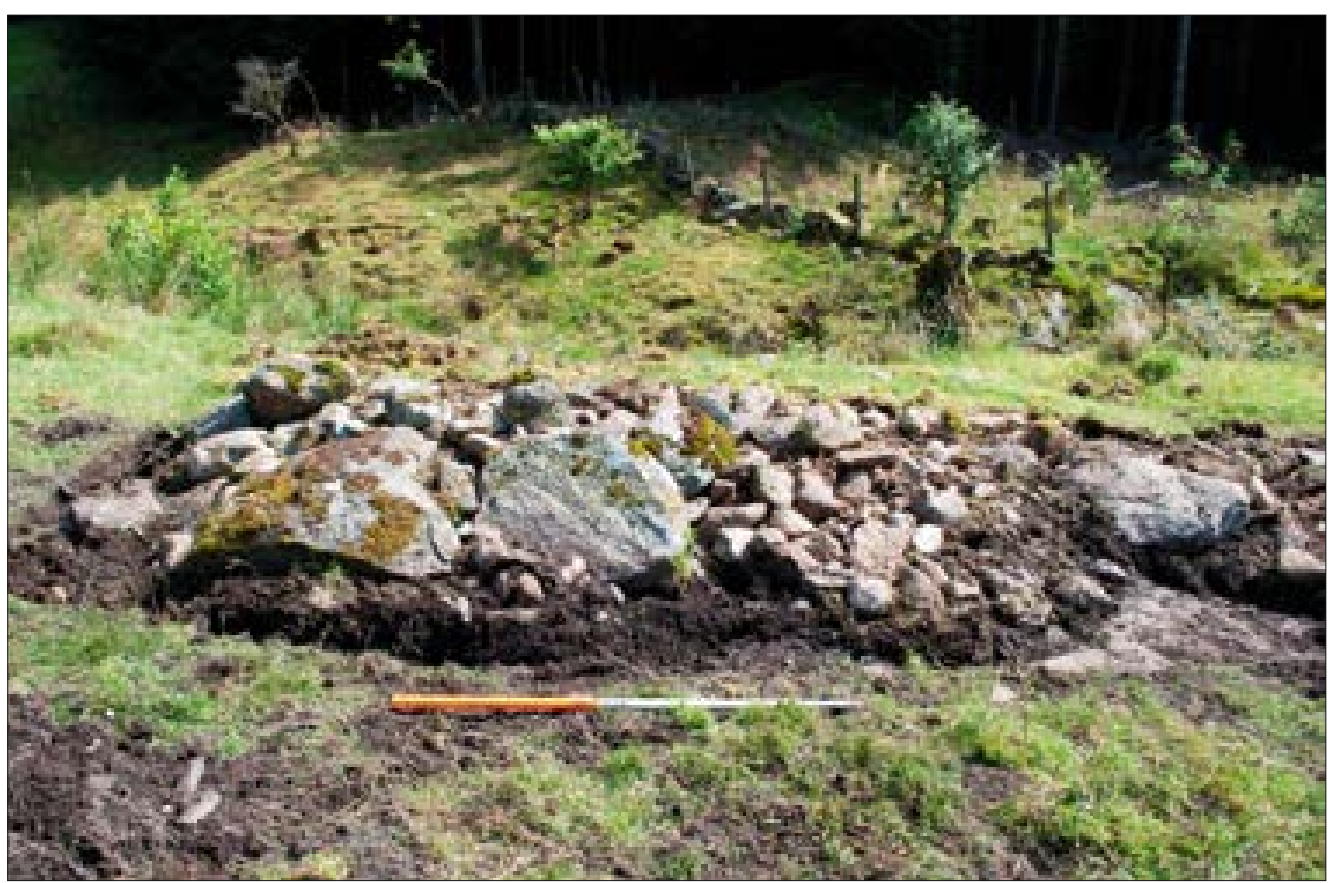

Fig. I. Rydningsrøys etter avtorving ved Smedsvik i Vindafjord kommune. Foto: Arkeologisk museum, UiS.

Fig. I. Clearance cairn fully uncovered at Smedsvik, Vindafjord municipality. Photo: Museum of Archaeology, University of Stavanger. 
Fig. 2. Gravrøys etter avtorving ved Smedsvik i Vindafjord kommune. Bildet i venstre hjørnet viser gjenstandsfunnene fra graven. Foto:

Arkeologisk museum, UiS.

Fig. 2. Burial cairn fully uncovered at Smedsvik, Vindafjord municipality. Inset shows the artefacts retrieved from the cairn. Photo: Museum of Archaeology, University of Stavanger.

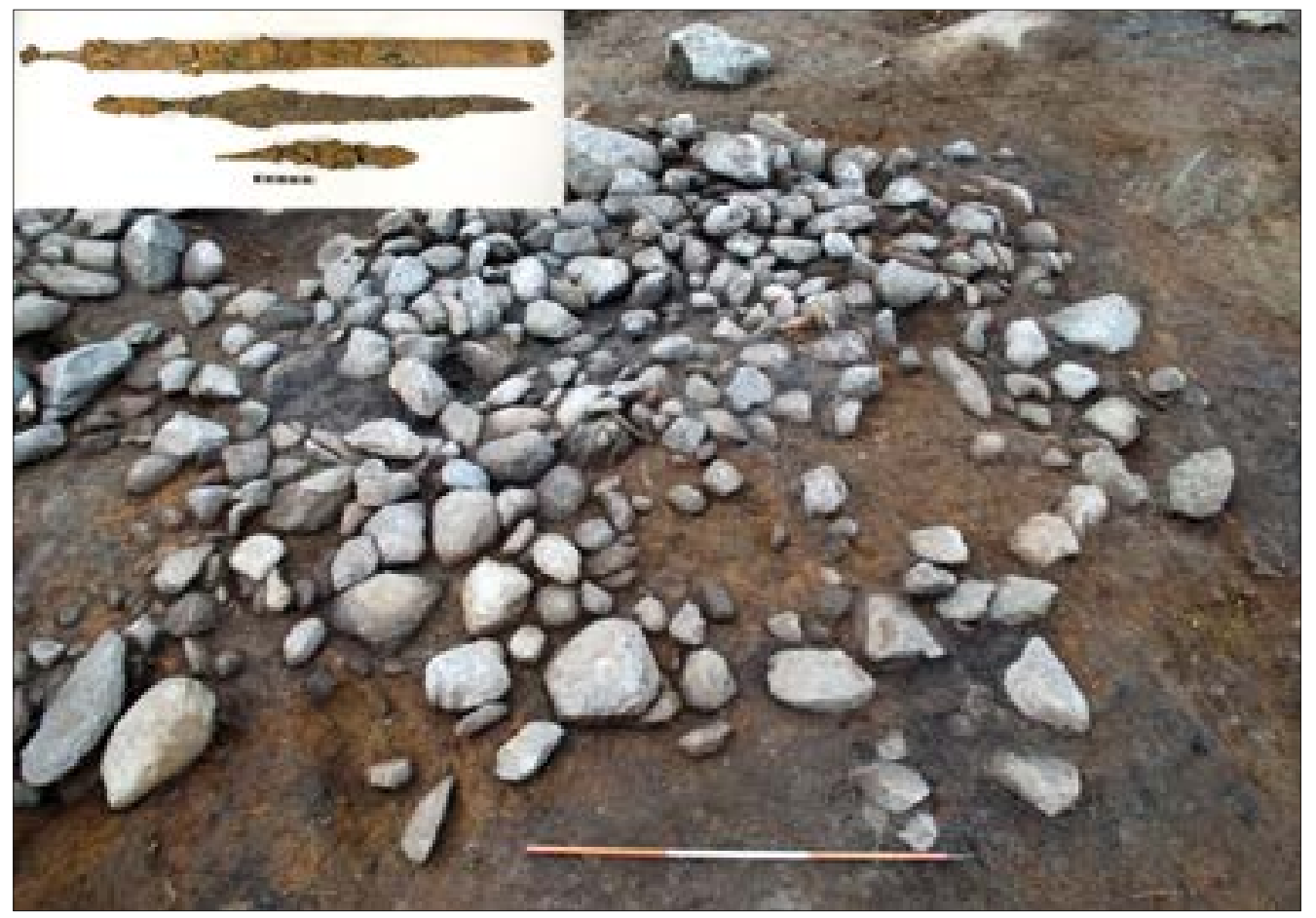

gravene. Skillet mellom rydningsrøysfelt og gravfelt bestående av små, funnfattige røyser blir derfor diffust og vanskeliggjør tolkningen.

I 2011 ble det gjennomført en utgraving i Smedsvik i Vindafjord kommune, hvor artikkelens problemstillinger eksemplifiseres godt. Utgangspunktet ved utgravingens start var at to rydningsrøyser og en mulig gravrøys skulle undersøkes. Planområdet var omgitt av flere tidligere kjente kulturminner, deriblant et gårdsanlegg og et gravfelt fra jernalder. Samtlige røyser som skulle undersøkes lå i tilknytning til en ryddet flate som var blitt undersøkt ved registreringen, og hvor det på flaten ble påvist et dyrkingslag (Fyllingen, 2008, s. 8). Ved selve utgravingen ble rydningsrøysene avtorvet og snittet og siden tolket til å være rydninger fra nyere tid, da de bestod av stein i varierende form og størrelse, deriblant noe sprengt stein (Fig. 1). Røysene inneholdt også tegl og porselen.

Den mulige gravrøysen lå $20 \mathrm{~m}$ unna og lå ytterst på en terrassekant. Derfra var det god utsikt mot sjøen. Etter avdekking viste røysa seg å være $8,5 \times 8 \mathrm{~m}$ og 0,5 m høy, samt den hadde ytre formelementer som kantkjede og homogene steinmasser. I tillegg var røysa intensjonelt oppbygd og hadde en klar avgrensing. Den inneholdt imidlertid ikke annet enn knust kvarts. Området rundt gravrøysa ble flateavdekket, og ytterlige to røyser ble påvist tett inntil den førstnevnte. Disse to røysene var ikke synlige på markoverflaten og var begge 4,5 $\mathrm{m}$ i diam og 0,3 $\mathrm{m}$ høye. Den ene av disse hadde jevn kantkjede, samt en indre sirkel av mindre steiner. Også i denne røysa ble det funnet knust kvarts, men ellers ingen gjenstandsfunn. Den siste røysa hadde i tillegg til kantkjede en avlang forsenkning i midtpartiet (Fig. 2), som ved nærmere undersøkelse viste seg å være et kollapset kammer. Kammeret hadde vært oppbygd av kantstilte heller, og i kammeret ble det blant annet gjort funn av et tveegget sverd, et tangespyd, en våpenkniv, et nålformet ildstål og et sølvbeslag som mest sannsynlig hadde prydet et bandolær (Bjørlo, 2012, s. 1). Funnene ble datert til overgangen folkevandringstid/ merovingertid.

Selv om bare en av de tre røysene inneholdt gjenstandsfunn, ble samtlige røyser tolket som gravrøyser ut fra beliggenhet, relasjonen til hverandre og utforming; kantkjede, homogene steinmasser, tydelig avgrensning og røysene var intensjonelt oppbygd. Samtidig var både høyde og diameter på to av røysene av så beskjeden karakter at uten full avdekking hadde de vanskelig latt seg klassifisere, om de i det hele tatt ville blitt funnet.

Da et entydig og sikkert skille mellom hva som er en liten gravrøys og hva som er en rydningsrøys er såpass problematisk, kan beliggenheten til kulturminnet ofte være tolkningsnøkkelen, spesielt i en registreringssituasjon. I denne sammenhengen kan arkeologisk landskapsanalyse bidra til en bedre forståelse av kulturminnenes beliggenhet. Plasseringen til gravhauger i terrenget varierer mye og kommuniserer forskjellige motivasjoner, men ved å kartlegge utsikten fra gravminnene og hva det er utsikt til, kan man få en oppfatning av hva de henvender seg til (Gansum, Jerpåsen \& 
Keller, 1997, s. 28). Innsyn er et begrep som benyttes for å beskrive eller vurdere hvordan et kulturminne henvender seg til landskapsrommet. Gravrøyser anlagt i nærheten av bevegelseslinjer viser at innsyn fra forbipasserende har vært av betydning ved valg av plassering. Røyser som ligger i skråninger nedenfor ryddede flater kan som regel ut fra relasjon og beliggenhet til andre fossile dyrkingsspor ses som et resultat av rydning. Ved å fokusere på hvordan røysene er plassert i kulturlandskapet, samt deres relasjon til andre kulturminner, kan man i noen tilfeller «avsløre» røysens funksjon. Metoden beror imidlertid på registrantens evne til å orientere seg og tolke relasjonene som finnes mellom de forskjellige elementene i landskapet. En tolkning av landskapet vil derfor alltid være en subjektiv prosess. Likevel kan man ut fra tidligere erfaringer ha en forhåndsoppfatning av hva man kan finne og hvor de ulike kulturminnetypene er plassert i terrenget. Etterhvert vil man kunne avdekket et «mønster» for hvor i landskapet rydnings- eller gravrøyser ligger plassert, noe som kan hjelpe i tolkningen av fornminnet (Gansum et al., 1997, s. 19-21).

I en registreringssituasjon er det med andre ord nødvendig å bruke tid i det landskapsrommet man befinner seg. For å forstå helheten som røysene inngår i, kan følgende punkt være relevante å avdekke:

\section{- Beliggenhet og topografi. Hvor i landskapet er} røysene plassert? Ligger røysene plassert på høyder eller terrassekanter? Kan de ha fungert som eiendomsmarkører? Finnes det framtredende landskapselement som røysene henvender seg til? Ligger de for eksempel i nærheten av myr, vann, elver eller veifar?

- Fravar eller tilstedevarelse av fossile dyrkingsspor. Finnes det åkerreiner, punktbrinker, bakkegjerder og/eller gardfar i nærheten? Er det ryddede flater i tilknytning til røysene og finnes det dyrkingslag i området?

- Relasjon til andre kulturminner. Er det andre kulturminner i nærheten som hulveier, hustufter, stakketufter, geiler og gardfar, og har de en relasjon til røysene?

En stor utfordring ved bruk av landskapsanalyse som tilnærmingsmetode er at kulturlandskapet stadig er i endring, noe som medfører at røysenes opprinnelige kontekst ofte vil være sterkt endret. Det kan derfor være fruktbart å trekke inn andre kilder i forsøk på å «gjenskape» det forhistoriske landskapet for å belyse røysenes funksjon. I denne sammenhengen kan eldre flyfoto avsløre tidligere myrområder og andre landskapselement, samt kulturminner som i dag er fjernet.

Bruk av Lidar-kart som metode gjør at man kan fremstille digitale terrengmodeller med høy detaljeringsgrad, også i områder hvor det finnes skog eller annen vegetasjon som dekker for den visuelle tilgangen til et landskap sett fra fugleperspektiv (Risbøl \& Gustavsen, 2016, s. 7-11). Lidar-kart kan avdekke røysfelt i områder med tett vegetasjon, samtidig som bruk av ulike terrengmodeller kan vise tidligere eller inntørka elveleier, noe som kan gi en økt forståelse av røysenes plassering i landskapet.

Bruk av jordsmonnkart innenfor arkeologien har også vist seg å være et nyttig redskap. Slike kart gir god oversikt over løsmasser i et område. Løsmasseforhold kan indikere hvilke områder som har vært egnet for bosetning i forhistorisk tid. I noen tilfeller kan jordsmonnskart vise til intensiv dyrking over lang tid ved at anthrosols, eller dyrkingslag, er blitt påvist.

Historiske kart og stedsnavn kan også være en nyttig kilde som blant annet kan gi informasjon om eldre veistrekninger, bebyggelse og eiendomsgrenser. Kartmaterialet kan i noen tilfeller anvendes for å studere forhold før kartenes tid. Eldre bebyggelsesnavn og jordbruksindikerende navn kan, sammen med andre historiske kilder, benyttes for å rekonstruere middelalderens bebyggelsesmønster. Kart som beskriver bebyggelse og markanvendelse i historisk tid kan også ofte benyttes for å få en økt forståelse av den forhistoriske markanvendelsen (Holm, 1995, s. 16; Jerpåsen, Sollund \& Widgren, 1997, s. 6; Øye, 2002, s. 35).

\section{Røysfelt registrert i forbindelse med E39 Ålgård-Hove}

Sommer og høst 2016 gjennomførte Rogaland fylkeskommune et større registreringsprosjekt, E39 Ålgård-Hove, i Sandnes og Gjesdal kommuner (Fig. 3). Bakgrunnen for prosjektet var at Statens vegvesen skulle utvide og forbedre E39 og deler av strekningen skulle legges i ny trasé. Registreringsprosjektet E39 Ålgård-Hove innebar både prøvestikking, maskinell sjakting og visuell overflateregistrering. Det ble til sammen påvist ti nye lokaliteter. I sju av disse ti nyregistrerte lokalitetene inngikk funn av røyser, hvor fire av lokalitetene ble funnet i forbindelse med sjakting $\mathrm{i}$ dyrket mark.

Under vil fire av røysfeltene som ble registrert i forbindelse E39 Ålgård-Hove bli presentert. Tolkningsgrunnlaget for de ulike lokalitetene varierer, og gjennomgangen vil vise hvilke metoder og kriterier som er blitt vektlagt i tolkningen for hvert av røysfeltene. 


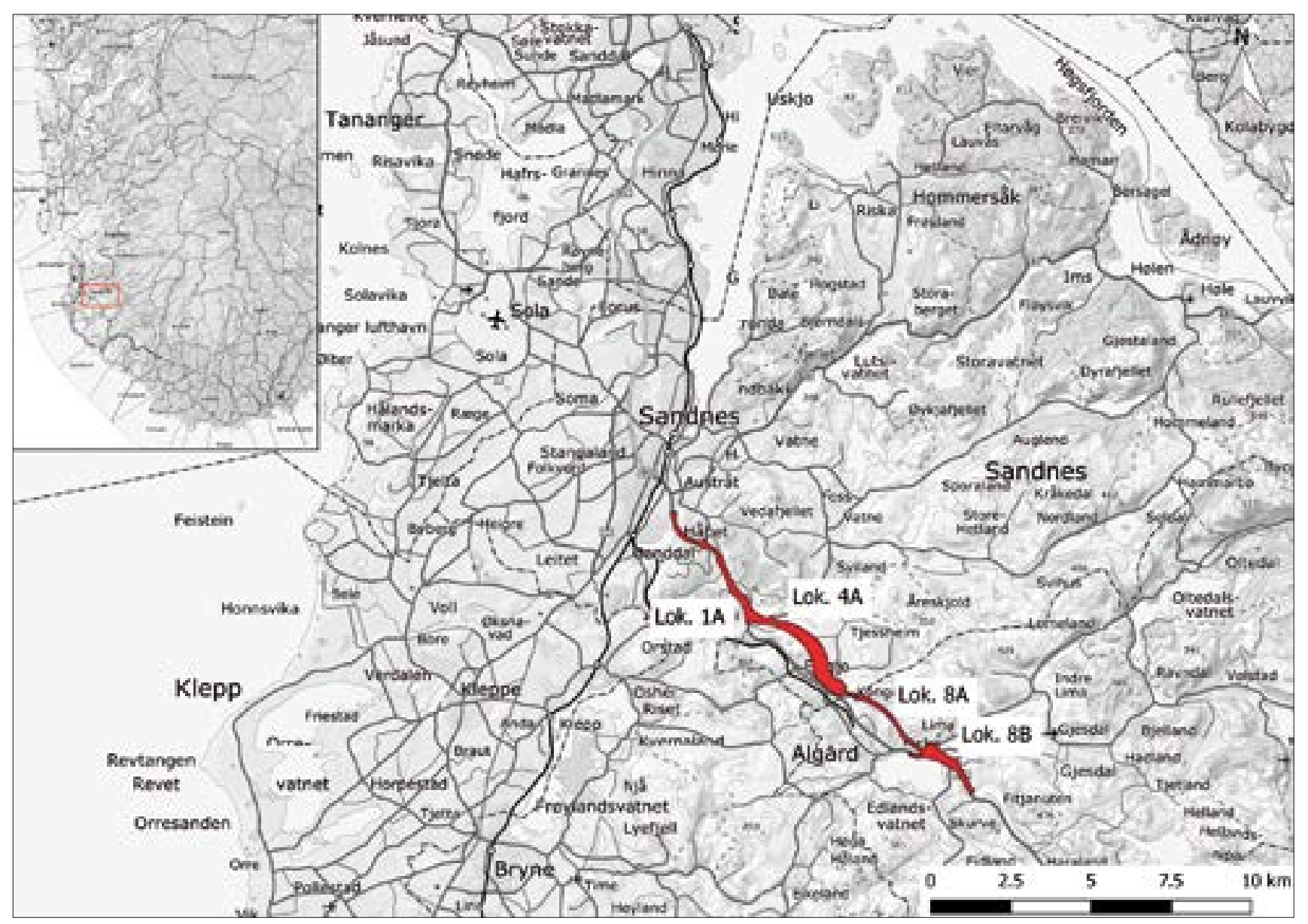

Fig. 3. Kartutsnitt av Sørvest-Norge. Vegtrasé E39 markert med rødt med omtalte lokaliteter inntegnet llustrasjon: Astrid H. Bjørlo. Fig. 3. Map showing southwestern Norway. The project area (E39) is marked with red, and the discussed localities highlighted. Illustration: Astrid H. Bjørlo.

Fig. 4. Kart over lokalitet IA med innmålte røyser og hulveitraséer ved Bråstein i Sandnes kommune. Illustrasjon: Astrid H. Bjørlo. Fig. 4. Map showing cairns and ancient paths/ roads registered on locality IA at Bråstein, Sandnes municipality. Illustration: Astrid H. Bjørlo.

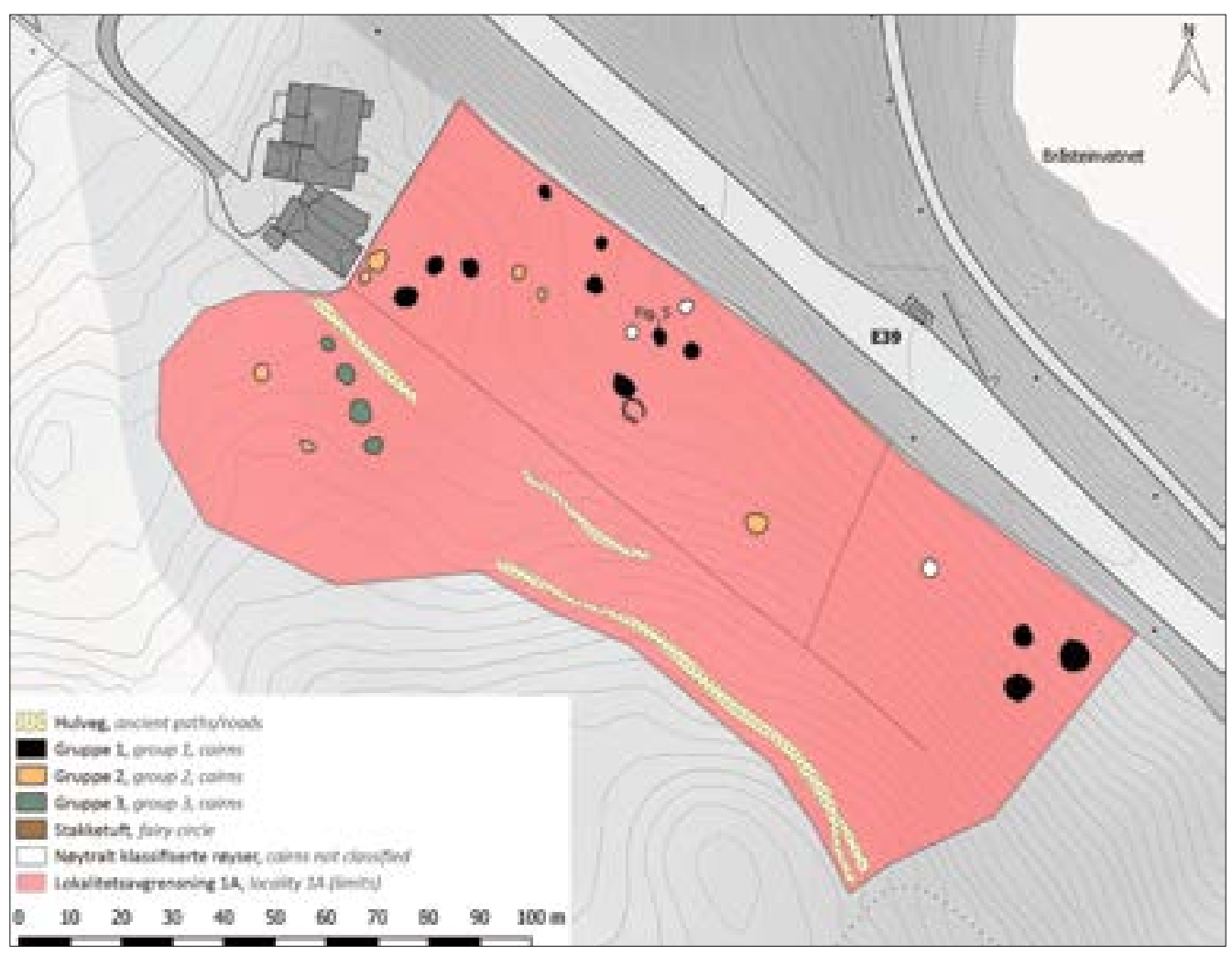




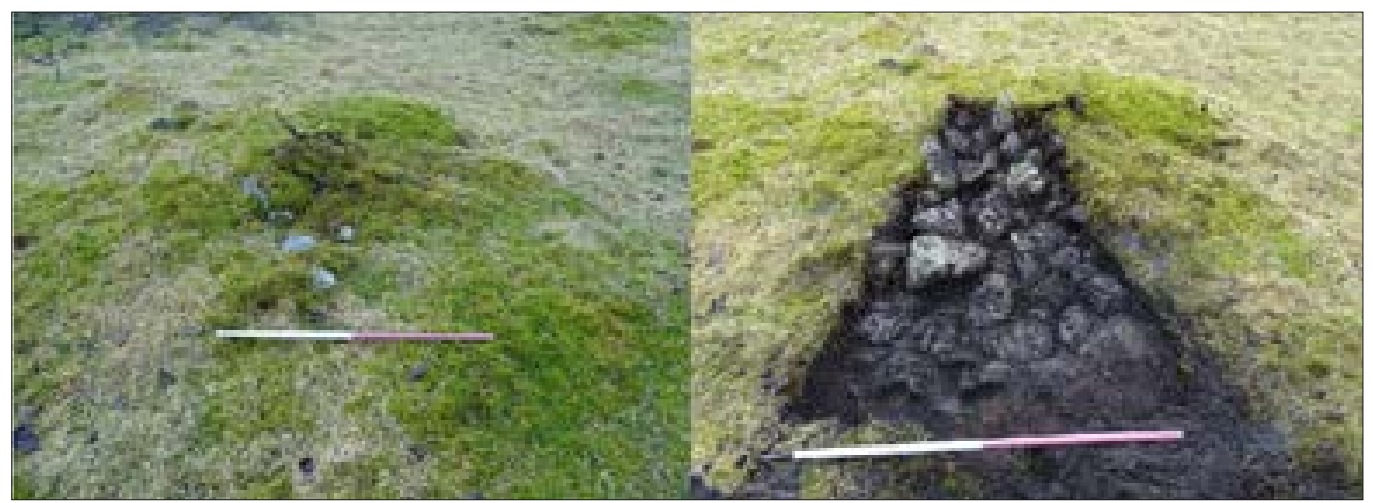

Fig. 5. Eksempel på røys før og etter delvis avtorving ved Bråstein i Sandnes kommune. Foto: Rogaland fylkeskommune. Fig. 5. Example of cairn before and after removing parts of the turf cover at Bråstein, Sandnes municipality. Photo: Rogaland County.

\section{Lokalitet 4A}

Lokalitet 4A ligger ved Bråstein i Sandnes kommune. I forbindelse med maskinell sjakting framkom det bosetningsspor og tre røyser. Røysenes hele flate ble avdekket, og de hadde en diameter på 2,5 m, 4,5 m og $5 \mathrm{~m}$. Selv om røysenes diameter var noe beskjeden, hadde de flere sterke indisier som pekte i retning av gravminne. De var runde i form og oppbygd av enkelte store steiner i ytterkanten. Ellers var de jevnt kuplet av homogene steinmasser. De to største røysene var noe flate i toppen som trolig skyldes pløying eller forsøk på utjevning. I tillegg til å ha en regelmessig og intensjonell oppbygning var det flere moment som gjorde at disse røysene med stor sikkerhet kunne tolkes som gravminner. Røysene er plassert ytterst på et platå, like sør for Bråsteinsvatnet, hvor det er fin utsikt over vannet og områdene rundt. Dette platået rommer flere registrerte gravhauger, og kulturminnene i området ble første gang registrert av konservator Tor Helliesen i 1903. I sine registreringer fra Bråstein nevner han at det har ligget ei gravrøys i det samme området der Rogaland fylkeskommunen påviste røyser under dyrket mark. Røysa som Helliesen omtaler, skal ha blitt utjevnet 60 år før han kom til stedet, og den hadde inneholdt en urne med brente bein, samt en gjenstand av jern som lignet et sverd eller spyd (Helliesen, 1904, s. 47). Med bakgrunn i Helliesens opplysninger, samt røysenes utforming og beliggenhet, kan disse tre røysene med stor sannsynlighet tolkes som gravminner.

\section{Lokalitet $1 A$}

Lokalitet 1A ligger $50 \mathrm{~m}$ nordvest for Bråsteinvatnet. Lokaliteten ligger i utmark og ble påvist i forbindelse med visuell overflateregistrering. Røysfeltet fordeler seg på og rundt sørsiden av en gresskledd ås. Fra åsen er det utsikt over den nordlige delen av Bråsteinvatnet. Innenfor lokaliteten ble det påvist 29 røyser, tre hulveitraséer, samt en mulig stakketuft (Fig. 4). To mindre flater mellom røysene framstår som delvis ryddet. Avstanden mellom røysene varierer og de er jevnt over lave $(0,2-0,4 \mathrm{~m})$ med en diameter på 2,5-5 $\mathrm{m}$. På grunn av røysenes beskjedne størrelse var noen av dem vanskelige å få øye på. I denne sammenhengen var Lidar-kart til stor hjelp både før og underveis i kartleggingen.

Det ble gravd seks mindre maskinelle sjakter innenfor lokaliteten for å se om det fantes strukturer eller eldre dyrkingslag, samt røyser som ikke var synlige på overflaten. Ingen av delene ble imidlertid påtruffet ved sjakting.

Røysene kan deles inn i tre grupper ut fra form og oppbygning (Fig. 4). Gruppe 1 består av 12 røyser som er lokalisert på og rundt åsen. Røysene framstår som svært lave, nesten i høyde med dagens torvflate, samtidig som de er tilsynelatende jevnt kuplet med neveog hodestore steiner. På grunn av usikkerhet knyttet til røysenes funksjon, ble tre røyser delvis avtorvet. Avtorvingen avslørte at røysenes reelle utstrekning var større enn først antatt. For eksempel var diameteren til den ene røysa $2,8 \mathrm{~m}$ på markoverflaten og $0,3 \mathrm{~m}$ høy. Etter avtorving var den reelle diamen 4,5 m, mens røysens høyde ble målt til 0,5 m (Fig. 5). Ellers framstod røysen som tydelig avgrenset, intensjonelt oppbygget og bestod av homogene steinmasser med enkelte kvartsknoller. De fleste røysene tilhørende gruppe 1 var helt eller delvis overgrodd, men på flere av røysene var det likevel mulig å observere en kantkjede.

To andre røyser hører også til gruppe 1, men de skiller seg ut når det gjelder beliggenhet og størrelse. De to røysene utgjør den sørøstlige avgrensingen av lokaliteten og begge har en diam på 5,5 m. De er hovedsakelig oppbygd av hodestore og større steiner. Den største røysa har en forsenkning i midten som trolig er et resultat av plyndring. Begge røysene var delvis overgrodde og ligger i en bratt og steinrik skråning som går ned til Bråsteinvatnet. I skråningen er det også flere naturlige steinavsetninger. Det var derfor usikkert hvorvidt det dreide seg om natur eller kultur da de først 
ble funnet. Den største røysa ble delvis avtorvet, og det ble avdekket en distinkt avgrensing, samt at den viste seg å ha en fin hvelvet profil.

Samlet sett er røysene tilhørende gruppe 1 blitt tolket som gravrøyser ut fra det intensjonelle preget, den jevne oppbygningen og formelementer som kantkjede og forsenkning/plyndringsgrop i midtpartiet.

Gruppe 2 består av sju røyser som er bygget inntil eller rundt en naturlig steinblokk eller jordfast stein. Steinsamlinger lagt inntil eller oppå jordfaste steiner blir som nevnt innledningsvis ofte tolket som rydningsrøyser. To av røysene med denne type utforming ligger imidlertid på toppen av åsen direkte på berg, noe som kan antyde en annen funksjon. I tillegg har begge røysene synlig kantkjede og gir et velbygd inntrykk. Det gir grunnlag for å tolke disse to røysene som gravminner (Fig. 6).

Samtidig var det flere andre røyser i gruppe 2 som var lagt inntil eller oppå en jordfast stein, men hvor det visuelle inntrykket peker i retning av rydningsrøyser. Noen av disse røysene ligger i nærheten av den ryddede flaten lengst vest i lokaliteten. Røysene virker mer tilfeldig i oppbygningen og har en uregelmessig form. Muligheten for at det er en gravrøys som siden har blitt tilført stein, virker mindre sannsynlig da røysen består av få steiner og hadde ingen ytre trekk som pekte i retning av grav. Fire av sju røyser i gruppe 2 er derfor tolket som rydningsrøyser.

Den tredje røysgruppen konsentrerer seg til lokalitetens nordvestlige del. Gruppe 3 består av fire røyser som ligger fint på rekke og tett opptil den ene hulveitraséen. Røysene skiller seg fra de andre røystypene ved at de er høyere og framstår som mer markante i terrenget. Diameteren varierer fra 3-5 $\mathrm{m}$ og de er mellom 40-50 $\mathrm{cm}$ høye. Den største røysa har et søkk i midten som trolig er spor etter plyndring. Røysene ligger nedenfor, og vest for åsen, hvor flesteparten av røysene fra gruppe 1 er lokalisert. Røysene tilhørende gruppe 3 ligger lavt i lendet, men de ser likevel ut til å være strategisk plassert i forhold til hulveien da de følger veiens retning. Hulveier går ofte gjennom eller forbi gravfelt, og gravene ble ofte lagt langs veien, da dette var en bevisst strategi for å holde minnet i hevd (Gansum, 2002, s. 34). Røysene i gruppe 3 blir ut fra form, oppbygning og relasjonen til hulveien tolket som gravrøyser.

I tillegg til de nevnte røysgruppene ble seks røyser nøytralt klassifisert som «røyser». Da det både ble påvist rydnings- og gravrøyser innenfor lokaliteten, og de gjenværende røysene ikke hadde noen framtredende formspråk, ble tolkningsgrunnlaget for snevert til å foreta en mer presis tolkning. Samlet sett ble 18

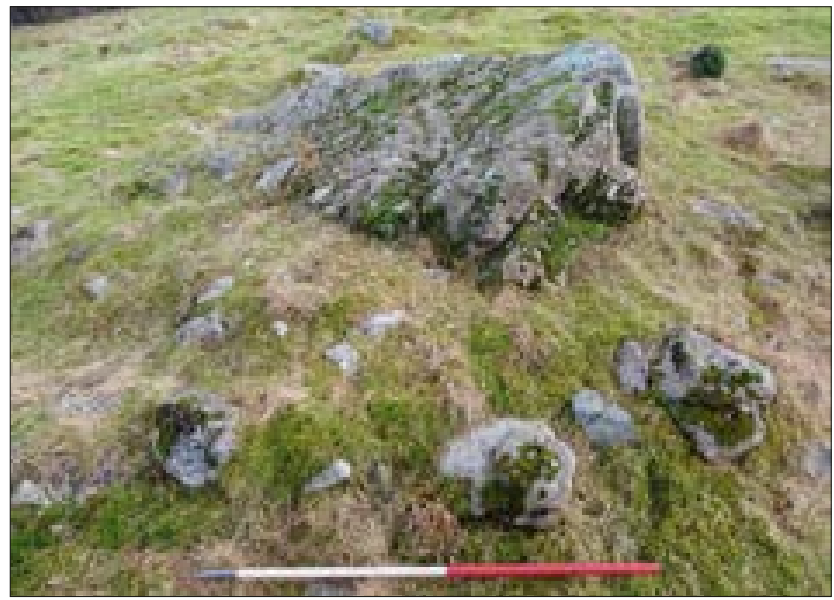

Fig. 6. Røys med kantkjede bygget rundt en naturlig steinblokk ved Bråstein i Sandnes kommune. Foto: Rogaland fylkeskommune.

Fig. 6. Cairn with perimetral kerbing build up around a natural deposited boulder at Bråstein, Sandnes municipality. Photo: Rogaland County.

av røysene på lokalitet 1A tolket som gravrøyser eller trolige gravrøyser og fire som rydningsrøyser. Når det gjelder røysfeltets plassering, er det flere interessante moment som kan dras fram. Røysfeltet er ikke plassert på det høyeste punktet i området, da et høyere og mer markert høydedrag ligger 100 meter sør for åsen. Fra denne bergtoppen er det utsyn over hele Bråsteinsområdet. På grunn av røysenes beskjedne utforming er de lite synlige i terrenget fra lang avstand. Innsyn, eksponering eller tilgjengelighet synes derfor ikke å ha vært hovedmotivasjonen for valget av gravplassen.

Ingen gjenstandsfunn ble avdekket på denne lokaliteten, men flere kvartsårer var synlig inni røysfeltet. Det ble observert kvartsknoller i overflaten på flere av røysene, samt også ved avtorving.

Forekomsten av kvarts i tilknytning til gravminner fra jernalderen har blitt påvist ved flere arkeologiske undersøkelser (Lindgren, 2008; Bjørlo, 2012; Solem \& Sauvage, 2015; Dahl, 2016). Hvilke religiøse eller symbolske forestillinger som ligger bak denne skikken, finnes det ulike teorier om, hvor blant annet steinens skarpe hvitfarge har blitt sett i forbindelse med fruktbarhet. Andre har trukket fram at tilstedeværelsen av knust kvarts i graver kan ses som metaforer for kremerte bein (Lindgren, 2008, s. 159). Kvarts har den egenskapen at det gir fra seg lys eller lysglimt hvis man gnir eller dunker steinene mot hverandre i mørke. Dette fenomenet heter triboluminescence, og steinens egenskap kan ha gjort kvartsen til et viktig innslag i en rituell sammenheng. Da det fantes synlige kvartsårer innenfor lokaliteten, er det vanskelig å avgjøre hvorvidt forekomsten av kvartsknoller i røysene er tilfeldig 
eller ikke, men dersom kvarts ble brukt i rituelle sammenhenger, kan kvartsårene i seg selv ha vært en medvirkende årsak til at den mindre åsen ble valgt som gravsted.

\section{Lokalitet $8 A$}

Lokalitet 8A ligger ca. 100 nordvest meter fra Limavatnet i Gjesdal kommune. I forbindelse med visuell overflateregistrering ble det funnet et røysfelt bestående av ti røyser. Røysfeltet ligger i en sørøstvendt og forholdsvis bratt og gresskledd skråning med fin utsikt over både Lima- og Edlandsvatnet. Fra området er det også fin utsikt over Vaula bru som er det eneste krysningspunktet mellom vannene. Lokalitet $8 \mathrm{~A}$ ligger $300 \mathrm{~m}$ vest for et stort og godt bevart gårdsanlegg på Fodnabergheia som består av flere hustufter, geiler, store gravrøyser og rydningsrøyser. Området som det nyregistrerte røysfeltet ligger i, preges av mange naturlig og overgrodde steinsamlinger og rasvifter. Flere av steinsamlingene framstod som mulige røyser, og med tanke på områdets beliggenhet og utsyn var det derfor heller ikke utenkelig at flere av røysene kunne være gravminner. Etter mye avtorving og vurdering ble resultatet ti røyser tolket som spor etter rydning. Grunnlaget for denne tolkningen er at røysene framstår som tilfeldig samlet sammen, inntil eller mellom jordfaste steiner (Fig. 7). Størrelsen på steinene varierer, og avtorvingen viste at røysene var utflytende $\mathrm{i}$ form og hadde ingen intensjonell oppbygning. Mellom rydningsrøysene er det to områder som framstod som ryddet. Flatene ble undersøkt ved hjelp av en mindre, håndgravd søkesjakt. Ingen dyrkingslag ble påvist i den forbindelse, og det er lite som tyder på at området har vært dyrket i forhistorisk eller historisk tid. Ingen

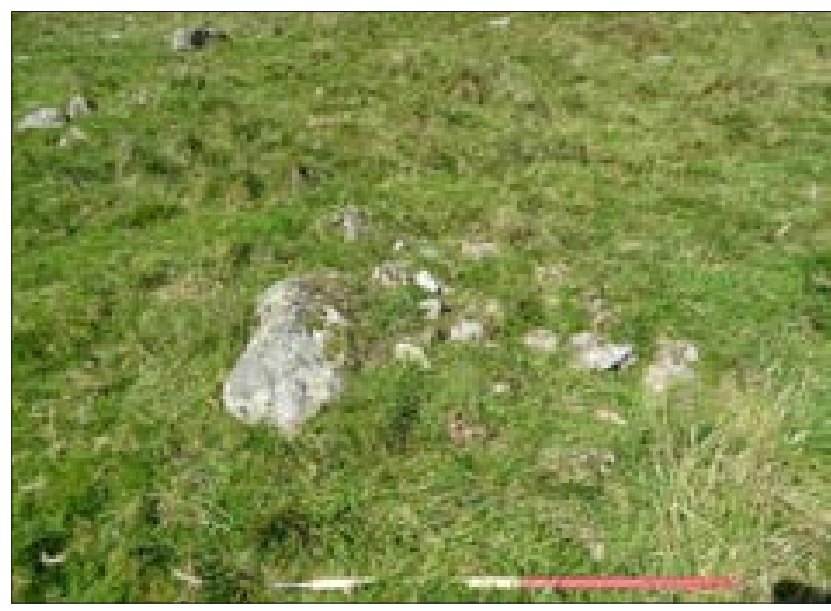

Fig. 7. Eksempel på rydningsrøys tilhørende lokalitet $8 \mathrm{~A}$ ved Limavatnet i Gjesdal kommune. Foto: Rogaland fylkeskommune. Fig. 7. Example of clearance cairn from locality $8 \mathrm{~A}$ at Limavatnet, Gjesdal municipality. Photo: Rogaland County. andre fossile dyrkingsspor ble påvist i området, så trolig er flatene ryddet til slåtteng eller beite.

\section{Lokalitet $8 B$}

Lokalitet 8B ligger $50 \mathrm{~m}$ nordvest for Limavatnet, og består av åtte røyser. Røysene ligger på en flate i bunn av ei steinur, men med fint utsyn utover Limavatnet. Røysene ligger tett opp mot Limaveien som fører opp til Limagarden, en gård som man kan følge tilbake til 1500-tallet i skriftlige kilder. Det er derfor nærliggende å anta at Limaveien som veifar har eksistert siden 1500-tallet, om ikke enda lengre tilbake i tid. Veien er også avmerka på historiske kart fra området. Det kan derfor tenkes at røysene kan ha hatt en relasjon til et eldre veifar i området.

Diameteren på røysene varierer fra 3-6 $\mathrm{m}$ og de er mellom 30-60 cm høye. Flesteparten av røysene er imidlertid sterkt forstyrret, da flere av dem er tilrotet og/eller at det er fjernet haugmasse fra dem. Noe av røysene er også forstyrret av større trerøtter. Området som røysene ligger i, har mye naturlig stein og steinblokker, og siden røysene var såpass forstyrret, var det derfor utfordrende å skille natur fra kultur i dette området. På Lidar-kart over området fremstår røysene imidlertid som forholdsvis tydelige.

Tre av røysene ligger i nærheten av en ryddet flate, noe som åpner for at det kan dreie seg om rydningsrøyser. Det ble gravd fire mindre maskinelle sjakter i tilknytning til denne flaten. I den forbindelse ble det påvist to kokegroper, samt at en forhøyning på marken ble bekreftet som røys. Røysen var oppbygd av hodestore eller større steiner og framstod som oval eller avlang i form. Det ble ikke observert noen klar kantkjede eller andre formelementer som peker i retning av gravminne, men røysen har et intensjonelt preg.

Ingen dyrkingslag eller andre fossile dyrkingsspor ble påvist i tilknytning til røysene, men røysene og kokegropene må ses i sammenheng med funnene som ble gjort på andre siden av Limaveien. Her ligger det en sørvendt og forholdsvis bratt skråning i dyrket mark som ble undersøkte ved hjelp av maskinell sjakting. I dette området ble det påvist bosetningsspor og flerfaset dyrkingslag som er datert til førromersk jernalder og merovingertid. Dyrkingslagene er lokalisert i nedre del av skråningen, så avstanden og den kraftige helningen øverst i området gjør det mindre sannsynlig å se røysene og dyrkingslagene i sammenheng. Røysenes plassering øverst på en flate med utsikt over vannet og en forhistorisk bosetning, samt en mulig relasjon til en eldre ferdselsvei, tyder heller på at røysenes funksjon er gravminner. 


\section{Oppsummering}

Gjennomgangen viser kompleksiteten knyttet til tolkning av røyser. For å skille rydning fra grav er det flere vurderingspunkt og metoder som må legges til grunn. Røysenes ytre trekk og beliggenhet kan trekkes fram som de viktigste. Samtidig er det relevant å avdekke fravær eller tilstedeværelse av fossile dyrkingsspor, samt røysenes relasjon til andre kulturminner. Graver er ikke tilfeldig plassert i landskapet, og det er konteksten som ofte er tolkningsnøkkelen, men å gjenfinne røysenes kontekst er krevende og finnes ikke alltid tilgjengelig. Da kan arkeologisk landskapsanalyse, sammen med blant annet eldre flyfoto, Lidar og jordmonnskart benyttes i prosessen med å forstå det forhistoriske landskapet $\mathrm{i}$ en registreringssituasjon. En nærmere forståelse av hvordan det forhistoriske landskapet har utviklet seg, kan bistå i tolkningen av røyser.

\section{Summary}

This article has highlighted the complexity associated with the classification of cairns. Separating natural stone piles from man-made structures, and clearance cairns from burial cairns, is a difficult task requiring a variety of methods. The cairn's form, its construction details, and its situation within the prehistoric landscape are viewed as being the most important factors. Determining the presence or absence of prehistoric agricultural remains is an important factor in assigning the function of a cairn. Even though the historical context may be washed away by modern activity, burial cairns are not randomly placed in the landscape. Seeing the cairn's relation to other cultural heritage sites in the vicinity is also important. Recreating the cairn's context, or lack thereof, is the key to understanding and interpreting them. Archaeological landscape analysis, combined with historic aerial photos, Lidar and soil identification maps, can all be useful tools in site registration, as well as in the analytical process of trying to determine a cairn's original function.

\section{Litteratur}

Bennett, A. (1987). Graven - religiös och social symbol: strukturer i folkvandringstidens gravskick i Mälarområdet (Doctoral dissertation). Universitetet i Stockholm.

Bjørlo, A. H. (2012). Arkeologisk undersøkelse av tre gravrøyser fra folkevandringstid/merovingertid: Smedsvik gnr. 170, bnr. 1, Vindafjord kommune (Oppdragsrapport B 2012/6). Arkeologisk museum, Universitetet i Stavanger.

Bortheim, K. \& Dahl, B. I. (2014). Arkeologisk undersøkelse av røysfelt fra E.BRA og bosetningsspor fra E.FØRROM $i$ Tjemslandsmarka: Tjemsland Nordre, gnr. 53, bnr. $1 \mathrm{og}$ 68, Hå kommune, Rogaland (Oppdragsrapport 2014/2). Arkeologisk museum, Universitetet i Stavanger.

Børsheim, R. L. (1997). Nye undersøkelser av Gauseldronningens grav. Frá haug og heiðni 4, 3-9.

Børsheim, R. L. (1999). Rydningsrøyser - en arkeologisk kildekategori. I L. Selsing \& G. Lillehammer (Red.), Museumslandskap. Artikkelsamling til Kerstin Griffin på 60-årsdagen. AmS-Rapport 12 B (s. 347-355). Arkeologisk museum i Stavanger.

Dahl, B. (2016). Haugen som gravfelt. I W. Brun \& E. S. Pedersen (Red.), Tverrfaglige perspektiver 3, AmS-Varia 58 (s. 77-95). Arkeologisk museum, Universitetet i Stavanger.

Dommasnes, L. H. (1997). Tradisjon og handling i førkristen vestnorsk gravskikk: Undersøkelser på et gravfelt på Vereide $i$ Gloppen, Sogn og Fjordane. Arkeologiske rapporter 21, Arkeologisk institutt, Museumsseksjonen, Bergen Museum, Universitetet i Bergen.

Fyllingen, H. (2008) Kulturhistoriske registreringer. Reguleringsplan for E134 Skjoldavik-Solheim, gnr. 168, 169 og 170, bnr. flere, Vindafiord k., 2008. Rogaland fylkeskommune, Regionalutviklingsavdelingen, Kulturseksjonen.

Fyllingen, H. \& Armstrong, N. J. O. (2012). Arkeologisk utgravning på Tjora, 10. bnr. 5, 17 og 19. Sola kommune, Rogaland. Sesong 2008 - id. 14854 og id. 158316 (Oppdragsrapport 2012/23A). Arkeologisk museum, Universitetet i Stavanger.

Gansum, T., Jerpåsen, G. B. \& Keller, C. (1997). Arkeologisk landskapsanalyse med visuelle metoder. AmS-Varia 28. Arkeologisk museum i Stavanger.

Gansum, T. (2002). Hulveger: fragmenter av fortidens ferdsel. Tønsberg: Kulturhistorisk Forlag AS.

Haavaldsen, P. (1999). Ajourføring av registrering av faste fornminner for Økonomisk Kartverk $i$ deler av Hå kommune, Rogaland, 1986. Top. Ark, Arkeologisk museum i Stavanger.

Helliesen, T. (1904) Oldtidslevninger i Stavanger Amt, Høyland (Vatne). Stavanger Museums Årshefte 1903, 31-74.

Hjelle, K. L. (2005). Pollenanalyse - en nødvendig metode for å forstå jernalderens jordbrukslandskap. I K. A. Bergsvik og A. Engevik (Red.), Fra funn til samfunn. Jernalderstudier tilegnet Bergljot Solberg på 70-årsdagen. UBAS Nordisk 1 (s. 91-104). Universitetet i Bergen.

Holm, I. (1995). Trekk av Vardals agrare historie. Varia 31. Oslo. Universitetets Oldsaksamling.

Holm, I. (2003). Spor etter folk i seinmiddelalderen - hva kan arkeologene fortelle, I H. R. Amundsen, O. Risbøl, \& K. Skare (Red.), På vandring i fortiden: mennesker og landskap $i$ Gråfjell gjennom 10000 år. NIKU-tema hefte Serie 7 (s. 83-87), Oslo. Norsk institutt for kulturminneforskning.

Hougen, B. (1924). Grav og gravplass: eldre jernalders gravskikk $i$ Østfold og Vestfold. Kristiania: i kommission hos J. Dybwad.

Jerpåsen, G., Sollund, M. L. B., \& Widgren, M. (1997). Historiske kart og kulturminnevern: En metode for landskapsanalyse. NIKU-Fagrapport 3. Oslo: Norsk institutt for kulturminneforskning.

Lindgren, C. (2008). Stones and Bones: The Myth of Ymer and Mortuary Practises with an Example from the Migration Period in Uppland, Central Sweden. I F. Fahlander \& T. Oestigard (Red.), The Materiality of Death. Bodies, Burials, Beliefs. BAR International Series 1768, (s. 155-160). Oxford: British Archaeological Reports.

Lillehammer, A. (1994). Fra jeger til bonde: inntil 800 e.Kr. Oslo: Aschehougs Norgeshistorie.

Løken, T. (1974). Gravminner i Østfold og Vestfold. Et forsøk på en typologisk-kronologisk analyse og en religionshistorisk tolkning. (Upub. Magistergradsavhandling.) Universitetet i Oslo. 
Myhre, B. (1985). Arable fields and farm structure. Archaeology and Environment, 1985 (4), 69-82.

Myhre, B., \& Øуе, I. (2002). Norges landbrukshistorie: jorda blir levevei. 4000 f.Kr.-1350 e.Kr. Oslo: Det Norske Samlaget.

Pedersen, E. A. (1990). Rydningsrøysfelt og gravminner spor av eldre bosetningsstruktur på Østlandet. Viking. Tidsskrift for Norrøn Arkeologi 53, 50-66.

Pedersen, E. A. (1999). Transformations to sedentary farming in eastern Norway: AD 100 or 1000 BC. I C. Fabech (Red.), Settlement and Landscape. Proceedings of a conference in Århus, Denmark. May 4-7 1998, (s. 45-52). Højberg: Jutland Archaeological Society.

Prøsch-Danielsen, L. (1999). Rydningsrøysa som pollenfelle og kilde til norsk jordbrukshistorie - innsamlingspolitikken i Rogaland. I L. Selsing \& G. Lillehammer (Red.), Museumslandskap. Artikkelsamling til Kerstin Griffin på 60-årsdagen. AmS-Rapport 12 B (s. 355-370). Arkeologisk museum i Stavanger.

Risbøl, O. \& Gustavsen, L. (2016). Bruk av luftbåren laserskanning (Lidar) i arkeologien. Håndbok. Norsk institutt for kulturminneforskning.

Rødsdalen, S. S. \& Bjørdal, E. (2017). Arkeologisk undersøkelse av røysfelt frå bronse og jernalder på Orstad gnr. 9, bnr. 8 og 15, Klepp k., Rogaland. (Oppdragsrapport 2015/10), Universitetet i Stavanger, Arkeologisk museum.
Rødsrud, C. (2004) Gravfelt fra førromersk jernalder og overgangen til romertid. I L. Melheim, L. Hedeager \& K. Oma (Red.), Mellom himmel og jord: foredrag fra et seminar om religionsarkeologi, Isegran 31. januar-2. februar 2002. OAS Vol. 2 (s. 274-290). Oslo: Institutt for arkeologi, kunsthistorie og konservering, Universitetet i Oslo.

Sjölin, M. (2015). Farstorp - ett röjningsröseområde med gravar. Komplexa stenrösen och stensättingar. I M. Petersson (Red.), Farstorp - ett röjningsröseområde $i$ långtidsperspektiv. Rapport 2015, Linköping: Arkeologiska uppdragsvirksomheten, Statens historiska museer.

Solberg, B. (2003). Jernalderen i Norge: ca. 500 f.Kr.-1030 e.Kr. Oslo: Cappelen akademiske forlag.

Solem, D. Ø. \& Sauvage, R. (2015). En gravrøys i sentrum. Trondhjemske Samlinger 2015, 107-110.

Wangen, V. (2009). Gravfeltet på Gunnarstorp i Sarpsborg, Østfold: et monument over dødsriter og kultutøvelse i yngre bronsealder og eldste jernalder. Norske Oldfunn XXVII. Oslo: Kulturhistorisk museum, Universitetet i Oslo.

Øye, I. (2002). Vestlandsgården - fire arkeologiske undersøkelser. Arkeologiske avhandlinger og rapporter 8. Arkeologisk institutt og Bergen Museum, De kulturhistoriske samlinger, Universitetet i Bergen, Bergen. 